Agricultural Service during 1911-15 and as entomologist to the British and Allied troops in Mesopotamia during 1916-17. From this latter appointment he was recalled to investigate the prevalence and control of malaria-carrying mosquitoes in Great Britain, and on completion of this work he joined the staff of the University of Sheffield, where he remained until 1929, by which time he had begun his well-known work on the breeding habits of earthworms. In 1929 he was appointed lecturer in zoology at Queen Mary College, London, became University reader and head of the Department in 1937 and University professor in 1947. For many years he was dean for medical students, but for the past two years he has acted as dean of the Science Faculty. Co-author of many text-books on zoological subjects and an authority on the breeding habits of Oligochætes, he will perhaps be best remembered by his colleagues in London for his work in building up the Zoology Department at Queen Mary College. The staff and students of the College will greatly miss his kindly interest in their many activities.

Dr. J. E. Smith

THE election of Dr. J. E. Smith as the successor to Prof. A. J. Grove is something more than a wellearned personal distinction, for it strengthens the bond of friendship established during the Second World War between the Departments of Zoology at Queen Mary College and Cambridge. Dr. Smith will need no introduction to his new staff, for they know, at first hand, both his ability as a teacher and his outstanding loyalty as a colleague. Dr. Smith has had an unusually wide range of teaching and research experience ; trained at King's College, London, he became a student probationer at Plymouth in 1930, and, after serving at Manchester and Sheffield, he was appointed lecturer and curator of invertebrates at Cambridge in 1938. As a teacher he has an almost unique ability of stimulating all grades of students and of putting life into what might otherwise be a somewhat unresponsive class. In the field of research he has opened up new and fruitful ground in the neurology of the echinoderms; it is to be hoped that he will be able to devote more and not less time to this most interesting work. Dr. Smith has, in addition to a heavy load of teaching and research, invariably been willing to carry his full share of administrative responsibilities. $\mathrm{He}$ was for several years both administrative officer of the Zoological Department at Cambridge and secretary of the Faculty Board of Biology. In both these capacities he will be remem. bered not only for his ability but also for his unfailing tact and good humour. Dr. Srnith's new appointment constitutes a very serious loss to Cambridge zoology; but he carries with him not only the good wishes of his immediate colleagues but also the universal affection of every member of his old Department.

\section{Large-Screen Television}

THE possibility of presenting television pictures of an adequate brightness on the large-size screen used in cinemas has been under development in Great Britain for some years. On April 29, the opportunity was taken by Messrs. Cinema-Television, Ltd., to demonstrate the state of this development by show. ing the B.B.C. Cup Final television programme to a selected audience of about a thousand persons, including television experts from some fifteen countries. The normal programme radiated from the Alexandra Palace transmitter was received in the neighbourhood of the Odeon Theatre, Penge, where the demonstra- tion was given. The received signals were conveyed to special equipment placed in the auditorium of the theatre at a distance of some 12 metres from the screen. A very bright image of the television picture, about $16 \mathrm{~cm} . \times 13 \mathrm{~cm}$. in size, was formed on a specia] cathode-ray tube operating from a hightension supply of 50 kilovolts. The optical projection system comprised a spherical mirror and plastic correcting plate by means of which the picture was thrown on to the theatre screen of approximate dimensions $6 \mathrm{~m}$. $\times 4.6 \mathrm{~m}$. A special metallized fabric directional viewing screen is used; this is perforated for sound and can thus be hung in front of the theatre speaker, by which the sound transmission was conveyed to the theatre audience. The projector demonstrated was designed to give a picture brightness comparable with that of normal film projection, with a high-light brightness of about 7 foot-lamberts, while the definition is naturally based on the 405-Iine standard of transmission of the B.B.C.

In spite of the fact that, owing to weather conditions, the daylight at Wembley was on the dull side, the demonstration was very satisfactory. Viewed from the theatre balcony at a distance from the screen of more than 30 metres, the brightness and quality of the picture were very good and enabled this annual climax in English association football to be followed with ease and great interest. No technical difficulties were experienced during the demonstration, and the equipment gave very satisfactory operation, which was quite uninterrupted except for the usual 'half-time' interval.

\section{Inter-African Information Bureau on the Con- servation and Utilization of the Soil}

AT the African Regional Scientific Conference, held in Johannesburg during October 17-28 (see Nature, November 26,1949, p. 901 ), a number of resolutions were passed for the setting up by Belgium, France, Portugal, the Union of South Africa and Great Britain of bureaux and permanent scientific committees in accordance with the policy of technical co-operation in Africa south of the Sahara. As a result of one such recommendation, the Inter-African Information Bureau on the Conservation and Utilization of the Soil has been set up in Paris. The Bureau gives practical effect to the wish of these countries to see the best use made of the land resources of Africa and to promote the economic and social development of the indigenous population. It will facilitate contact and establish permanent liaison between regional African committees on soil conservation, the InterAfrican Pedological Service, and all experts and national and international bodies concerned with these problems. The address of the Bureau is Muséum National d'Histoire Naturelle, 47 Rue Cuvier, Paris.

\section{The British Bryological Society}

THE annual general meeting and excursion of the British Bryological Society was held at Totnes, Devon, during April 12-19, under the presidency of Prof. P. W. Richards. About forty members were present, including one foreign member, Prof. R. van der Wijk (Groningen, Holland). Visits were made to Holne Bridge, Wistman's Wood, Bolt Head and other places of interest. It was decided to open the Society to junior members under the age of twenty-one (or, if students, twenty-five), who would have the privileges of other members, including that of receiving the Society's Transactions, but not the right to vote or 